TI 2017-060/V

Tinbergen Institute Discussion Paper

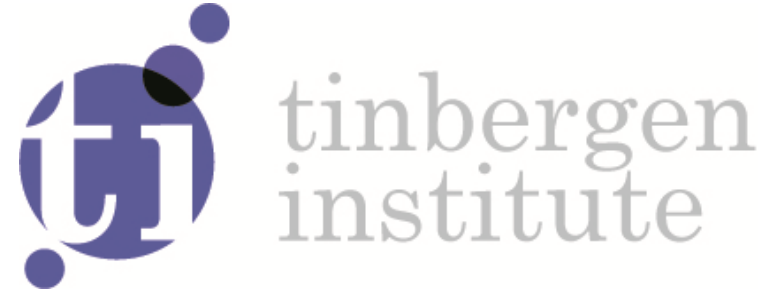

\title{
Pension Rules and Labour Market Mobility
}

Marloes Lammers ${ }^{1}$

Hans (H.G.) Bloemen ${ }^{2}$

Stefan (S.) Hochguertel ${ }^{3}$

1: SEO Economic Research, Netherlands

2: Vrije Universiteit Amsterdam, The Netherlands; IZA, Germany; Netspar, The Netherlands; Tinbergen Institute, The Netherlands

3: Vrije Universiteit, The Netherlands; Netspar, The Netherlands 
Tinbergen Institute is the graduate school and research institute in economics of Erasmus University Rotterdam, the University of Amsterdam and VU University Amsterdam.

Contact: discussionpapers@tinbergen.nl

More TI discussion papers can be downloaded at the Tinbergen Site

Tinbergen Institute has two locations:

Tinbergen Institute Amsterdam

Gustav Mahlerplein 117

1082 MS Amsterdam

The Netherlands

Tel.: +31(0)20 5984580

Tinbergen Institute Rotterdam

Burg. Oudlaan 50

3062 PA Rotterdam

The Netherlands

Tel.: +31(0)10408 8900 


\title{
Pension rules and labour market mobility*
}

\author{
Marloes Lammers†, Hans Bloemen, Stefan Hochguertel \\ Vrije Universiteit Amsterdam, SEO Economic Research, Tinbergen Institute, and Netspar
}

This version: June 2017

\begin{abstract}
This paper makes use of a natural experiment to examine effects of potential capital losses and general attractiveness of pension schemes on employees' propensity to change jobs. On January 1st 2004, the two largest pension funds in the Netherlands, for civil servants and for the health care sector, changed their pension scheme from a final salary to an average salary.

This industry-leve change excludes the possibility that a negative correlation between having a job with an attractive pension scheme and the number of labour market transitions is driven by self-selection of workers into jobs with an attractive pension arrangement. Using individual data covering the entire Dutch population, we estimate discrete choice models for job-to-job transitions. The results show that the number of job transitions of civil servants significantly increased at the onset of the new pension rules. The changing pension rules affected the propensity to change jobs for individuals working in the health care sector only to a smaller extent.
\end{abstract}

Keywords: Discrete Choice Models, Policy Evaluation, Labour market flexibility, Pension Systems JEL classification: C35, J26, J32, J63

\footnotetext{
${ }^{*}$ We are grateful for useful comments and suggestions from Agar Brugiavini, Pilar Garcia-Gomez, Marike Knoef, Julia le Blanc, participants of seminars at Leiden University, the Netspar Pension Workshop in Utrecht, the UCFS Workshop in Sweden, SEO Economic Research, the Netspar International Pension Workshop in Amsterdam and the ESEM in Gothenburg. All remaining errors are our own.

${ }^{\dagger}$ Corresponding address: SEO Economic Research, Roetersstraat 29, 1018WB Amsterdam, the Netherlands. Tel.: +31 20 52516 32. E-mail address: M.Lammers@seo.nl
} 


\section{Introduction}

A dynamic labour market in which employees are not constrained in their job choice offers a range of advantages. When firms need to readjust their workforce following a change in micro- or macro-economic conditions, labour market flexibility is needed to allocate the right employee to the right job. (Long-term) unemployment can be predicted to be lower in environments where workers can easily flow between firms (Di Tella and MacCulloch, 2005). A possible drawback of high mobility of labour is that firms underinvest in general training and education if they face difficulties to retain highly mobile and productive employees. An important contribution in the ongoing discussion on the value of flexible labour markets is to identify rules and institutions that form obstacles to job transitions. Specifically, the accrual of pension benefits is a co-determinant of the financial benefits of any job, thereby affecting the attractiveness of a job offer. Backloaded pension arrangements with an increasing marginal effect on pension benefits in the few years prior to retirement comprise very different incentives to switch jobs than plans that are neutral with respect to past and future tenure in the firm. Especially when pension rights are not perfectly transferable, potential pension capital losses can prevent an individual from switching jobs. This makes pension provision a potential determinant of 'job lock', which is the phenomenon that workers stay in their current job because leaving their job will lead to a decrease in employee benefits (Gruber and Madrian, 1994).

Studies testing the effects of (early) retirement pensions on labour market behaviour have usually been concerned with the retirement decision of the elderly. ${ }^{1}$ Yet, financial incentives embedded in the pension system also affect job decisions in mid-career. Mitchell (1982) was the first to empirically show the negative correlation between job turnover and pension provision. Estimating probit models, she shows that the probability of male individuals changing jobs between 1974 and 1977 drops by 20 percent when the job offers a(ny) pension plan. Surprisingly, other fringe benefits seem to have no significant effect on labour market mobility. A summary of early theories on the impact of pension plans on employees' behaviour can be found in Allen and Clark (1987). These theories propose several hypotheses for the correlation between pensions and mobility. The first hypothesis posits that imperfect mobility of pension rights decreases mobility of individuals covered by a pension plan, because job transitions are associated with pension capital losses. Second, less switch-prone individuals might self-select into jobs with pensions: for example because the potential pension capital loss associated with a job change is not relevant when an individual does not intend to quit his job (Ippolito 1991). A final reason for lower turnover in jobs that offer pension plans comes from the fact that these jobs are generally more attractive, also in other respects.

In order to offer a cleaner estimate of the causal effect of pensions on labour market transitions, empirical studies have tried to correct for the selection of less mobile individuals into jobs that offer a pension plan. Examples are the inclusion of random effects (Mealli and Pudney, 1996) and the use of occupational pension offer rates by region of residence as an instrument for occupational pension coverage (Andrietti, 2004).

\footnotetext{
${ }^{1}$ Examples of such studies include Burtless and Moffitt (1984) for the U.S., Börsch-Supan and Schnabel (1998) for Germany and Euwals, van Vuuren and Wolthoff (2010) for the Netherlands.
} 
Allen, Clark and McDermed (1993) use a simultaneous equation model to show that observable employee characteristics can explain both higher job turnover as well as coverage by a pension plan. They interpret this as evidence for a selection effect on observables.

We base our findings on a natural experiment offered by a variation in pension rules applying to some workers and not to others. Specifically, on January 1st 2004, the two largest pension funds in the Netherlands (one covering about 1.1 million civil servants, the other about the same number of health care workers) changed their defined benefit (DB) pension scheme from a final salary system to an average salary system. A final salary system promises workers with a pension equal to a certain percentage of the wage earned in the final year(s) of work, whereas an average salary system promises workers a pension equal to a certain percentage of the average wage earned over the entire working life. We have access to detailed administrative data sources comprising the entire Dutch population. Importantly, all relevant job transitions can be measured in order to detect a possibly subtle effect of pension rules on job transitions. We select two treatment groups and a control group representing about $45 \%$ of the total number of Dutch employees. Relying on this rich source of data, we estimate discrete choice models for job-to-job transitions. The results show that the number of job transitions of civil servants and health care professionals significantly increased at the onset of the new pension rules. However, whereas one would expect that especially career-making individuals switch jobs from a DB-average salary scheme, this was not the case for civil servants and health care professionals. It therefore seems that although individuals are driven by a major change in their pension scheme, they are either not interested in, or do not understand the details of their pension accrual.

The primary focus of pension design is on offering consumption smoothing and income insurance possibilities for retirees, trading off return risk of capital investment with risks of demographic nature and changing labor market participation patterns. However, economists have long come to recognize that feedback effects of pension institutions on labour market participation and employment behavior can be of considerable importance (see Thomas and Spataro 2014 for a review). For instance, whether pensions are of the defined benefit or of the defined contribution type may matter for labor market transitions between employers, as the system design directly affects portability (Andrietti and Hildenbrand 2016 is a recent study). Traditionally, the majority of funded pension schemes in the OECD were of the DB type (OECD, 2016). Most OECD countries have adapted their DB systems over time and use lifetime earnings to calculate pension benefits (OECD, 2015). Examples of countries that have extended the period over which earnings are taken into account are France, Finland, Poland, Portugal, the Slovak Republic and Sweden (Martin and Whitehouse, 2008).

To the best of our knowledge this paper is the first one to shed light on the consequences of moving to an average salary system for labour market mobility.

This paper contributes to the existing literature in two important ways. The first contribution is that we use a large change of industry standard to identify the causal effect of a change in pension rules. By studying the same individuals covered by two different pension schemes, we can convincingly exclude the possibility 
that the found correlation between mobility and pension schemes is driven by self-selection into jobs with an attractive pension arrangement. ${ }^{2}$ The second contribution is that the specific rules according to which pension accrual takes place may not create financial incentives that affect job choices and job mobility, where previous work showed that the provision of a(ny) pension scheme does matter for job mobility.

The remainder of this paper is set up as follows: Section 2 sketches the institutional context. Section 3 offers theoretical effects of a switch from a DB-final salary to a DB-average salary plan, focussing on the variation in potential pension capital losses incurred in both systems. Section 4 presents the data and some descriptives. The correlation between the type of pension plan (DB-final, DB-average and DC) and number of job transitions is shown. The results of the main regression analysis are given in Section 5 before turning to conclusions in Section 6.

\section{Institutional Context}

\subsection{The Dutch pension system}

A full pension of a Dutch individual consists of a maximum of three components. First, everyone aged 65 or above receives a flat rate basic state old age pension, which is financed on a pay-as-you-go (PAYG) basis, meaning that current workers' contributions pay for current pensioners' benefits. From age 15 to age 65, every calendar year that an individual resides in the Netherlands, he or she accrues $2 \%$ of full rights to a state pension. A full state pension equals $100 \%$ of the legal minimum net wage for couples, and $70 \%$ of the minimum wage for singles ${ }^{3}$.

Second, over $90 \%$ of employees is covered by a capital-funded occupational pension scheme. The occupational pension schemes are operated by pension funds. There are pension funds that cover a profession or an entire industry, while firm level pension funds exist for some large companies. General regulations, for example concerning the favorable tax treatment of pension premiums are laid down in the Law on Pensions (PensioenWet, PW). The exact specifications of the occupational schemes are part of labour market negotiations and specified in collective labour agreements. These agreements are made either at the industry or at the firm level. When agreements are made at the industry level, the Ministry of Social Affairs can require an entire sector to participate in the same pension fund if formally requested by the employers' organizations and trade unions leading the negotiations. For employees, participation in the occupational pension scheme is effectively mandatory. ${ }^{4}$ The implication of this is that workers can change pension funds only by changing to a job in an industry covered by a different pension fund.

In 1998, most pension arrangements were of the defined benefit (DB) type, whereas a small percentage

\footnotetext{
${ }^{2}$ Ippolito (2002) also uses a natural experiment: in 1984 the pension system for federal government employees in the U.S. was replaced by a new, less generous system which implied a lower capital loss when switching jobs. However, since only new entrants were covered by the less generous system, a selection effect cannot be excluded.

${ }^{3}$ These provisions are meant to guarantee a minimum standard of living, while accounting roughly for household size.

${ }^{4}$ There are some exceptions, see also Section 4.
} 
Figure 1. Percentage of pension fund participants covered by various pension plans

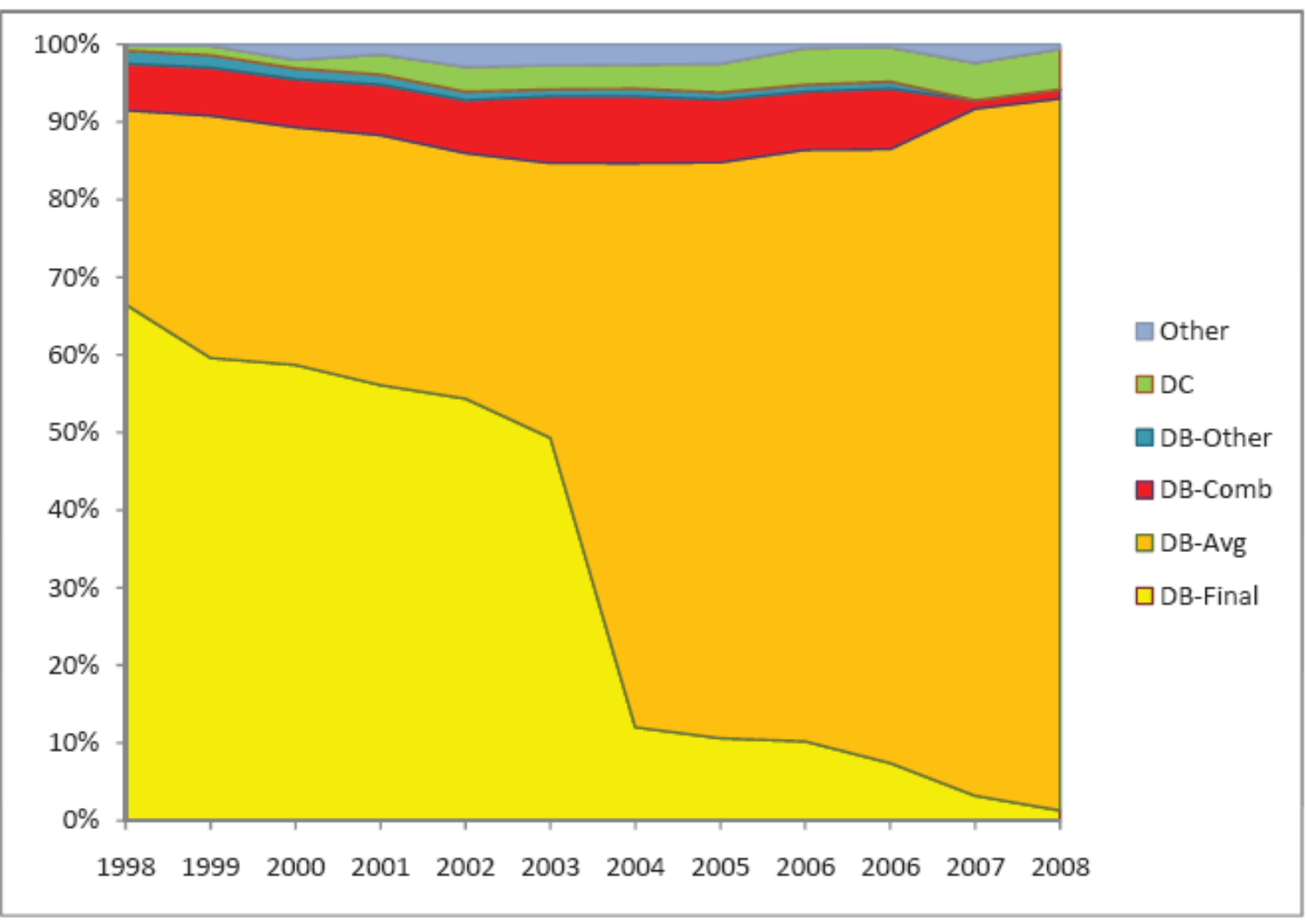

from 2006 on: excl. pension funds close to liquidation

was based on a defined contribution (DC) scheme. In the latter system, pension capital is treated as an investment, the proceedings of which are paid out as pensions. Payments are therefore directly dependent on realized (stock) market returns. The pension benefits from a DB scheme are pre-specified, with participants accruing a small percentage of their final or average wage every year. Table 1 shows that the typical employee in 1998 was covered by a final-pay DB scheme with a yearly accrual rate of $1.75 \%$, assuring a $70 \%$ gross replacement rate after a labor market history of 40 years. ${ }^{5}$. In most occupational pension schemes, participants start accruing pension rights immediately: the vesting period is legally maximized at two months for regular employees. The final component of a full pension system consists of individual pensions bought from insurance companies, and other personal savings that are used as an old-age-provision. Because of the importance and generosity of occupational pensions, this component on average provides only $7 \%$ of total income of the elderly (Bovenberg and Meijdam, 1999).

\footnotetext{
${ }^{5}$ This $70 \%$ gross replacement rate includes payments from both the occupational pension and the basic state pension, since usually occupational pensions are based on the wage over and above a 'franchise' (an amount usually based on the level of state pension payments). Net replacement rates tend to be significantly higher for many retirees.
} 
Table 1. YEARLY ACCRUAL RATES OLD AGE PENSION

$\begin{array}{lllllll}>1,5 & 1.5 & 1,5- & 1.75 & 1,75-2 & 2 & >2\end{array}$

1,75

\begin{tabular}{lllllllll}
\hline \hline \multicolumn{7}{c}{ Percentage of pension funds } \\
1998 & 3.3 & 1.9 & 2.8 & 61.0 & 3.4 & 8.5 & 1.8 & 17.4 \\
1999 & 3.3 & 1.7 & 2.9 & 59.7 & 3.9 & 8.9 & 2.2 & 17.5 \\
2000 & 3.5 & 1.4 & 2.6 & 59.2 & 4.8 & 9.5 & 1.9 & 17.0 \\
2001 & 3.8 & 1.3 & 3.1 & 58.0 & 5.4 & 10.6 & 2.5 & 15.3 \\
2002 & 3.9 & 1.2 & 2.8 & 55.3 & 7.4 & 12.0 & 3.4 & 14.1 \\
2003 & 3.6 & 1.1 & 3.1 & 51.0 & 9.1 & 14.0 & 4.9 & 13.2 \\
2004 & 3.7 & 1.2 & 3.4 & 49.7 & 10.1 & 14.1 & 5.5 & 12.4 \\
2005 & 3.8 & 1.0 & 3.5 & 46.5 & 10.2 & 15.5 & 7.1 & 12.5 \\
2006 & 4.0 & 1.0 & 3.6 & 43.6 & 10.7 & 16.9 & 8.0 & 12.4 \\
$2006^{*}$ & 4.3 & 1.2 & 3.9 & 42.8 & 11.3 & 17.7 & 9.0 & 9.7 \\
2007 & 3.7 & 0.0 & 3.9 & 26.8 & 9.6 & 18.6 & 37.4 & 0.0 \\
2008 & 3.4 & 0.0 & 3.7 & 26.9 & 10.3 & 18.1 & 37.5 & 0.0
\end{tabular}

\section{Percentage of participants}

\begin{tabular}{lllllllll}
1998 & 12.0 & 0.1 & 1.9 & 74.2 & 0.3 & 3.1 & 0.4 & 7.9 \\
1999 & 11.3 & 0.1 & 1.8 & 72.5 & 2.4 & 3.2 & 0.6 & 8.1 \\
2000 & 11.2 & 0.1 & 1.7 & 72.4 & 3.2 & 3.5 & 0.7 & 7.3 \\
2001 & 11.5 & 0.1 & 1.8 & 65.8 & 9.1 & 4.7 & 1.9 & 5.1 \\
2002 & 11.8 & 0.1 & 1.6 & 63.8 & 10.1 & 5.3 & 2.2 & 5.1 \\
2003 & 5.3 & 0.1 & 1.6 & 58.5 & 12.7 & 5.6 & 6.8 & 9.4 \\
2004 & 4.5 & 0.1 & 1.6 & 37.9 & 32.6 & 6.7 & 7.4 & 9.1 \\
2005 & 4.4 & 0.1 & 1.5 & 39.0 & 31.6 & 6.6 & 7.8 & 9.1 \\
2006 & 4.1 & 0.1 & 1.6 & 35.7 & 30.7 & 6.0 & 9.5 & 12.4 \\
$2006^{*}$ & 4.2 & 0.1 & 1.7 & 37.4 & 32.4 & 7.0 & 10.0 & 7.1 \\
2007 & 1.6 & 0.0 & 3.6 & 3.4 & 7.6 & 6.3 & 77.5 & 0.0 \\
2008 & 1.8 & 0.0 & 4.9 & 2.8 & 8.1 & 5.8 & 76.7 & 0.0 \\
\hline
\end{tabular}

*Note: from 2006 pension funds that are close to liquidation are no longer reflected in the statistics.

The general increase in accrual rates from 2007 onwards is a result of the abolition of the favourable fiscal treatment of savings for early retirement pensions. Many pension funds compensated their employees by increasing the yearly accrual rate of pension wealth. 


\subsection{From Final to Average Salary Schemes}

The typical pension fund in 1998 offered their participants a final-pay DB scheme. From 1999 onwards, various reasons led many pension funds to abandon the final-salary scheme in favour of an average-salary DB system: (1) unfavourable stock market returns, (2) an aversion to 'reverse solidarity' that existed between career- versus non-career-making employees, and especially, (3) the employer risk associated with backservice payments. (4) An added advantage of the average-salary system is that valorisation could be made conditional on the performance of the pension fund. In a final-salary system only pensioners are struck by temporary non-indexation of their rights, whereas in an average-salary system it is possible to adjust valorisation and indexation rates of all participants: active members, sleepers, and pensioners (Ponds and van Riel, 2010). ${ }^{6}$

On the 1st of January 2004, the two largest Dutch pension funds, the pension fund for civil servants (ABP) and for the health care sector (PGGM, now PFZW), switched from a final-salary to an averagesalary plan. ${ }^{7}$ Figure 1 shows that around $30-35 \%$ of total Dutch active pension participants were affected by these changes. ${ }^{8}$ Dutch civil servants and health care professionals come from all layers of society: government officials and medical doctors are included, but so are the employees who perform administrative tasks, nurses, and those that keep the streets clean and safe. Since so many individuals were directly touched by these policy changes, this natural experiment offers an exceptional possibility to meaningfully estimate the effect of the type of pension plan on job transitions.

Previous work posits that there are three mechanisms that can explain a positive correlation between having a job with an attractive pension arrangement and labour market mobility: (1) selection of less switchprone indviduals in jobs with an unattractive pension (2) jobs with good pensions are generally more attractive and (3) potential pension capital losses. In particular the first two mechanisms are of importance for assessing the credibility of the empirical approach. We comment in turn. (1) Self-selection cannot drive our results. First, since the new rules were immediately applied to current participants of the system, we are able to compare behaviour of the same individuals before and after the policy change, effectively eliminating the selection effect. Second, even without a natural experiment the self-selection issue is mitigated by studying the effect of particular characteristics of a pension scheme on the propensity to move (Henley,

\footnotetext{
${ }^{6}$ Indexation refers to the adjustment of payments to pensioners to reflect changes in costs or standards of living. Valorisation is the adjustment of past earnings to account for changes in living standards between the time when pension rights are earned and when they are claimed (OECD, 2005). An individual that has some pension rights with a pension fund but is currently not an active participant is called a sleeper.

7 The professional military services kept a final-salary system in 2004 since an average-salary system was thought not to be able to account for the diverging salary structure and legal position of military personnel. The military is therefore not included in the data analysis.

8 According to Statistics Netherlands, there were 841 pension funds in 2004 with a total number of 6,268,000 active participants (i.e. employees). Although the large majority of the pension funds were firm-specific funds, the 102 sector-specific funds covered in total 5,320,000 or $85 \%$ of the total number of active participants (Statistics Netherlands, 2012). The treatment funds in our sample are the largest funds: both contained more than 1 million active participants or about $16 \%$ of total participants each in 2004. The third largest pension fund (PMT for the metal industry) 'only' covered 418,000 active participants in 2009.
} 
Disney and Carruth,1994). Although it is in principle possible that individuals self-select into jobs with the type of pension scheme according to their implicit switching probabilities, this may require a more sophisticated calculus than a simple membership decision. (2) General attractiveness of the pension scheme can drive our results, since an average salary scheme is less attractive for individuals with high expected wage rises, thereby encouraging them to switch jobs when they are no longer covered by a final salary scheme. Section 3 elaborates on the characteristics of individuals who are more likely to switch jobs when the final salary system is replaced with an average salary system. However, switching to an employer who still offers a DB-final-salary plan is not an issue since only $12 \%$ of pension fund participants was still covered by a DB-final-salary scheme in 2004 (Figure 1). Since the pension funds that did offer a DB-final-salary scheme in 2004 mainly covered jobs in the technical and construction industry, substitution to these type of jobs seems practically irrelevant for civil servants and those working in the health care sector.

\section{A theoretical model of transferable pension rights}

This Section considers the individual-specific incentives involved in the job change decision in the situation where the current pension plan is a DB-final-salary scheme versus the situation where the current pension plan is a DB-average-salary scheme. From these theoretical incentives, a number of hypotheses are derived and tested in Section 5. We consider an individual facing a decision to either switch jobs to an employer covered by a different pension fund or to stay with the current employer. Our focus is on a specific part of the financial incentives involved in the decision to switch, namely the attainable per-year pension at age 65, $P$. We will use a star $(*)$ to denote the value of variables with a different employer, non-starred symbols are used to denote the value of variables at the current employer.

In the following, we are mainly interested in the conditions under which $P^{*}>P$, i.e. the yearly pension rights at age 65 when taking up a job with an employer that has a different pension fund is higher than the yearly pension rights at age 65 when staying in the current job (with the current pension fund). Whenever $P^{*}>P$, there is an incentive to switch $\left(I T S^{\Delta f u n d}\right)$ in terms of attainable pension rights. This incentive is composed of two parts:

1. Whether the future value (i.e. the value at age 65) of the pension rights that have already been accrued at the moment of the job transition will increase or decrease. In the equations for $P$ below, this is reflected in the first part of the equation. For future reference, we will label the discrepancy between the value of current pension rights when a switch takes place and the value of current pension rights when not switching jobs IT $S_{\text {current }}^{\Delta \text { fund }}$.

2. Whether the future value (i.e. the value at age 65) of the pension rights that still need to be accrued after the job transition takes place will increase or decrease. In the equations for $P$ below, this is reflected in the second part of the equation. For future reference, we will label the discrepancy between 
the value of future pension rights when a switch takes place and the value of future pension rights when not switching jobs IT $S_{\text {future }}^{\Delta \text { fund }}$.

An individual working in a job for a salary $S_{t}$ in year $t$ for a total of $n$ years decides whether or not to make a transition to a new job. His salary is expected to rise at a constant rate $w$ each year, such that $S_{t+1}=S_{t}(1+w)$. In case he stays in the same job (or switches to an employer covered by the same pension fund as his current employer), his pension rights are assumed to accrue for a total of $N$ years. In case he changes jobs, his pension rights accrue for a total of $n$ years with his old employer, and $N-n$ years with his new employer. Let the yearly accrual rate of pension rights be denoted by $x$ and the valorisation of active and sleeper rights by $r_{A}$ and $r_{S}$, respectively. ${ }^{9}$ In order to be able to single out the incentive to change jobs for individuals covered by an average versus a final salary plan, we assume that the new job and the old job have the same expected wage increase: $w=w^{*}$ and that all pension systems are exactly the same in terms of accrual rates $x$ and valorisation $r_{A}=r_{S}=r .^{10}$

\subsection{Final salary to final salary switch (at time $n<N)$}

First take an individual working in a job with a DB-final-salary (FS) system. When staying in the current job for the maximum number of $N$ years, per-year pension payments at age 65 are: ${ }^{11}$

$$
P^{F S}=x S_{N} N=x S_{n}(1+w)^{N-n} N
$$

When changing jobs after $n$ years, attainable yearly pension at age 65 when the new job also has a DB-final-salary plan will be (in case an individual will not transfer (NT) his accrued pension rights to his new employer):

$$
P_{N T}^{* F S}=x S_{n}(1+r)^{N-n} n+x S_{n}^{*}\left(1+w^{*}\right)^{N-n}(N-n)
$$

Comparing equations (1) and (2), it is clear that switching between employers that are insured with different pension funds can bring about major changes in an employee's pension rights when those rights cannot be transferred to the new employer. A decrease in the future value of the accrued pension wealth can occur, since the rights that have been acquired from the previous employer will not rise with future increases in wages: there is no backservice over non-transferred rights. It depends on the rules concerning

\footnotetext{
${ }^{9}$ Footnote 6 explains valorisation and sleeper rights.

10 For some pension funds, indexation of sleeper rights is lower than indexation of active rights (an often encountered indexation is a correction for the average wage rise in the sector for active rights, and an inflation correction for sleeper rights). However, since both ABP and PGGM apply the same indexation for both types of rights, we abstract from this.

11 When we denote indexations $(r, w)$ to be net of inflation from time $n$, these equations can be thought of present values of the yearly pension at age 65 . We assume an individual expects to live until age 65 with certainty. Also, we abstract from issues related to differing mortality tables and interest rates used by the current and new employer. Introducing parameters which are not directly relevant for our analysis (because no discontinuous shift in them takes place in the period studied) leads to a more complex notation which will distract the reader from the main argument presented in this section.
} 
the valorisation of sleeper rights $r$ to what extent the value of pension rights built up with the previous employer will rise in value. That is, accrued pension rights will decline in value upon changing employers whenever $w>r$. In other words, IT $S_{\text {current }}^{\Delta \text { fund }}$ is negative when $w>r$ and positive when $w<r$.

To repair this obstruction for employees to switch jobs whenever $w>r$, a new law was passed, becoming effective on July 8th 1994. The law established standard calculation rules on the basis of which pension rights can be transferred from one pension fund to another (on request by the employee). However, until January 1st 2007 pension rights could not be transferred to (or from) profession-specific pension funds. For jobs to which rights could be legally transferred, the present value of the rights is calculated and is treated as if it were accrued in the pension fund of the new employer. In case of a transfer between DB-final salary plans, this includes the provision of backservice over the transferred pension value. ${ }^{12}$ The yearly attainable pension at age 65 when switching between DB-final salary plans and transferring $(\mathrm{T})$ accrued pension rights will be:

$$
P_{T}^{* F S}=x S_{N}^{*} N^{*}=x S_{n}\left(1+w^{*}\right)^{N-n} n+x S_{n}^{*}\left(1+w^{*}\right)^{N-n}(N-n)
$$

with

$$
\begin{aligned}
N^{*} & =N+\left(n^{*}-n\right) \\
n^{*} & =n\left\{\frac{x}{x} \frac{S_{n}}{S_{n}^{*}}\right\}
\end{aligned}
$$

Where $n^{*}$ is calculated from equalizing the value of the pension with the old employer when the individual would retire now, with the value of the pension with the new employer when the worker would retire now:

$$
S_{n} x n=S_{n}^{*} x n^{*}
$$

As we can see from comparing equations (1) and (3), as long as the final attainable salary in both jobs is the same $\left(S_{N}=S_{N}^{*}\right)$, some pension rights are lost when a promotion is made at the moment of transfer $\left(S_{n}^{*}>S_{n} \rightarrow N^{*}<N \rightarrow P_{T}^{* F S}<P^{F S}\right)$. In this case the employee does not accrue pension rights over the increment in salary for the time spent with the old employer, since in the past there was no pension accrual over this extra salary. The number of years $n^{*}$ transferred to the new employer is therefore lower than the actual number of years worked $n$. Since a salary increase with the current employer does lead to a full backservice, it can be financially more attractive to accept a small salary increase with the current employer, as compared to a larger increase in salary with the new employer. It decreases the mobility of a career-making employee covered by a DB-final salary plan, even when he has an option to transfer his accrued rights to the new pension fund. In other words, IT $S_{\text {current }}^{\Delta \text { fund }}$ is negative when $S_{n}^{*}>S_{n}$. Moreover, an individual covered by a DB-final-salary plan will be reluctant to accept a demotion with an employer

\footnotetext{
${ }^{12} \mathrm{~A}$ switch between employers does not have to be immediate: a period of unemployment between jobs is no obstruction to the right to transfer. Transferring pension value is not possible when the coverage rate of one or both pension funds is below $100 \%$. In this case a transfer can still be requested, such that the actual transfer can take place at the moment the coverage rate of both pension funds is above $100 \%$.
} 
that is covered by the same pension fund, whenever he cannot make up for the decrease in salary at some later point in time. In this case, the future value of his pension rights will decrease in value: every accrued working year is now valuated against a lower salary. That is, IT $S_{\text {current }}^{\text {same fund }}$ is negative when $S_{n}^{*}<S_{n} \cdot{ }^{13}$

\subsection{Final salary to average salary switch (at time $n<N)$}

In case a switch takes place from a DB-final salary to a DB-average-salary plan, pension rights at age 65 when not transferring these rights will be:

$$
P_{N T}^{* A S}=x S_{n}(1+r)^{N-n} n+x \sum_{t=n+1}^{N} S_{n}^{*}\left(1+w^{*}\right)^{t-n}\left(1+r^{*}\right)^{N-t}
$$

Whereas using a transfer of the current pension value translates in an accumulation of pension rights at age 65 of:

$$
P_{T}^{* A S}=x S_{n}\left(1+r^{*}\right)^{N-n} n+x \sum_{t=n+1}^{N} S_{n}^{*}\left(1+w^{*}\right)^{t-n}\left(1+r^{*}\right)^{N-t}
$$

Therefore, an individual is indifferent to the decision to transfer accrued pension rights or not under our assumptions. Moreover, pension rights are lost whenever $w>r$. Since this affects both the pension rights already accrued and the pension rights to be accrued in the future, there is a negative incentive to switch $\left(I T S^{\Delta f u n d}\right)$ in a final-salary plan for individuals with high expected future wage increases. Vice versa, the incentive to switch is positive when $w<r$.

\subsection{Average salary to average salary switch (at time $n<N)$}

Now take an individual working in a job with a DB-average-salary system. When staying in the current job for the maximum number of $N$ years, per-year pension payments at age 65 are:

$$
P^{A S}=x \sum_{t=1}^{N} S_{t}(1+r)^{N-t}
$$

When an individual transits to another job with a DB-average-salary plan, the total accrued yearly pension value at age 65 when not transferring current pension rights will be:

$$
P_{N T}^{* A S}=x \sum_{t=1}^{n}\left\{S_{t}(1+r)^{n-t}\right\}(1+r)^{N-n}+x \sum_{t=n+1}^{N} S_{n}^{*}\left(1+w^{*}\right)^{t-n}\left(1+r^{*}\right)^{N-t}
$$

Whereas with a transfer of accrued pension rights the yearly pension at age 65 reads:

$$
P_{T}^{* A S}=x \sum_{i=1}^{n}\left\{S_{t}(1+r)^{n-t}\right\}\left(1+r^{*}\right)^{N-n}+x \sum_{t=n+1}^{N} S_{n}^{*}\left(1+w^{*}\right)^{t-n}\left(1+r^{*}\right)^{N-t}
$$

\footnotetext{
${ }^{13}$ Since the number of accrued pension years is especially high for the elderly, the Dutch law allows for the continuation of pension rights on the old (higher) level for individuals facing a demotion from age 55.
} 
As is clear from equations (9) and (10), under our assumptions an individual is indifferent between transferring and not transferring accrued pension rights. Moreover, no pension rights are lost in case of a switch between two average salary systems with equal parameters.

\subsection{Average salary to final salary switch (at time $n<N)$}

The resulting yearly attainable pension at age 65 when switching from a job with a DB-average-salary-plan to a job with a DB-final-salary-plan is

$$
P_{N T}^{* F S}=x \sum_{t=1}^{n}\left\{S_{t}(1+r)^{n-t}\right\}(1+r)^{N-n}+x S_{n}^{*}\left(1+w^{*}\right)^{N-n}(N-n)
$$

when not transferring accrued pension rights and

$$
P_{T}^{* F S}=x \sum_{t=1}^{n}\left\{S_{t}(1+r)^{n-t}\right\}\left(1+w^{*}\right)^{N-n}+x S_{n}^{*}\left(1+w^{*}\right)^{N-n}(N-n)
$$

when transferring accrued pension rights. That is, an individual for whom $w>r$ will transfer his rights and has an incentive to switch $\left(I T S^{\Delta f u n d}\right)$ to a job with a final salary plan. Note that, since both current and future pension rights become more valuable, both $I T S_{\text {current }}^{\Delta \text { fund }}$ and $I T S_{\text {future }}^{\Delta \text { fund }}$ are positive. In contrast, when $w<r$ rights will not be transferred and there will be a negative incentive to switch. Since only future pension rights are negatively affected only $I T S_{\text {future }}^{\Delta \text { fund }}$ is negative in this case.

\subsection{Hypotheses derived from theoretical incentives}

Table 3 summarizes the theoretical effects of coverage by a DB-final-salary versus a DB-average-salary scheme on the incentive to switch. For example, an individual who is covered by a DB-average salary plan and for whom $w>r$ has a positive incentive to switch to an employer with a DB-final-salary plan (ITS $\left.S^{\Delta f u n d}\right)$. On the other hand, an individual who is covered by a DB-final-salary plan and for whom $w>r$ has a negative incentive to switch to an employer with a DB-final-salary plan. Every fifth line indicates the expected increase or decrease in the number of job transitions from January 1st 2004 on, when the pension funds ABP and PGGM changed their pension system from final to average salary. For the group of individuals for whom $w>r$, the number of job transitions is expected to increase since they now face a positive instead of a negative incentive to switch.

It is likely that the majority of individuals has $w>r$ instead of $w<r$ since valorisation $r$ is never higher and often lower than the median salary rise in a sector. This is a direct consequence of the fact that in the first few years of the 21st century, the valorisation rate $r$ was usually pegged to the basic wage increase (agreed upon in collective labour agreements) which is added to the wage of all workers. ${ }^{14}$ In fact,

\footnotetext{
${ }^{14}$ Nowadays, valorisation is usually pegged to price increases instead of wage increases, in order to keep the valorisation rate low.
} 
the pension fund for the civil servants ABP increased yearly accrual rates from $1.75 \%$ per year to $1.75 \%$ $1.9 \%$ per year in order to make the switch from final- to average-salary benefit-neutral for the average ABP participant - see Table 2. However, ABP also increased the joint premium for both old age occupational pension and widow(er)s pension from $15.2 \%$ in 2003 to $19 \%$ in 2004 (the employee pays $\frac{1}{4}$ of the total premium). Moreover, most participants agreed to pay the full premium (1.7\%) for the widow(er)s pension themselves, in order to avoid that the payments of widow(er)s pension after the individual turns 65 would get cut in half. Civil servants therefore on average did not experience a cut in future pension benefits but did experience an increase in today's costs in 2004. The pension fund for the health care sector PGGM did not raise valorisation rates or premiums in 2004. Health care workers therefore were likely to experience a cut in future pension benefits but did not experience an increase in today's costs.

Table 2. Changes in accrual rates - civil servants

\begin{tabular}{llll}
\hline & $\begin{array}{l}\text { Age on } \\
12-31-2003\end{array}$ & Accrual rate & Franchise \\
\hline \hline 2003 scheme & all & $1.75 \%$ & 15,450 \\
& & & \\
\multirow{2}{*}{2004 scheme } & $<40$ & $1.9 \%$ & 13,000 \\
& $40-49$ & $1.8 \%$ & 14,250 \\
& $>49$ & $1.75 \%$ & 15,250 \\
\hline
\end{tabular}

Note: since the state offers a basic pension to every Dutch citizen, it is unnecessary to accrue pension wealth over the entire salary. The franchise is the part of salary over which no pension wealth is accrued. For employees of at least 50 year of age the adjustments are minimal, since for them salary is not expected to rise much.

From Table 3, a number of testable hypotheses can be derived:

Hypothesis 1: Individuals with high expected wage increases $(w>r$ ) are more likely to switch jobs (to an employer with a different pension fund) when their current pension plan is of the DB-average-salary form.

When a career-making individual covered by a DB-final-salary-plan switches to an employer with an average salary plan he loses part of his current and future pension rights when making the switch. In contrast, a career-making individual covered by a DB-average-salary-plan will gain in terms of both current and future pension rights.

Hypothesis 2: Individuals with low expected wage increases $(w<r$ ) are less likely to switch jobs (to an employer with a different pension fund) when their current pension plan is of the DB-average-salary form.

When a non-career-making individual covered by a DB-final-salary-plan switches to an employer with an average salary plan he gains both current and future pension rights when making the switch. The same individual also has an incentive to switch to an employer with another final salary plan since in that case he can choose for his current pension rights to be indexed by $r$ instead of $w$. In contrast, a non-career-making individual covered by a DB-average-salary-plan will lose in terms of future pension rights. 
Table 3. Theoretical effects of pension system on number of job switches

\begin{tabular}{|c|c|c|c|c|c|c|}
\hline & & $I T S_{\text {current }}^{\Delta \text { fund }}$ & $I T S_{\text {future }}^{\Delta \text { fund }}$ & $I T S^{\Delta \text { fund }}$ & $I T S_{\text {current }}^{\text {samefund }}$ & $I T S^{\text {total }}$ \\
\hline \multirow[t]{4}{*}{$w>r$} & $\mathrm{AS} \rightarrow \mathrm{FS}$ & + & + & + & 0 & + \\
\hline & $\mathrm{AS} \rightarrow \mathrm{AS}$ & 0 & 0 & 0 & 0 & 0 \\
\hline & $\mathrm{FS} \rightarrow \mathrm{FS}$ & 0 & 0 & 0 & 0 & 0 \\
\hline & $\mathrm{FS} \rightarrow \mathrm{AS}$ & - & - & - & 0 & - \\
\hline \#switches 2004 & & & & + & 0 & + \\
\hline \multirow[t]{4}{*}{$w<r$} & $\mathrm{AS} \rightarrow \mathrm{FS}$ & 0 & - & - & 0 & - \\
\hline & $\mathrm{AS} \rightarrow \mathrm{AS}$ & 0 & 0 & 0 & 0 & 0 \\
\hline & $\mathrm{FS} \rightarrow \mathrm{FS}$ & + & 0 & + & 0 & + \\
\hline & $\mathrm{FS} \rightarrow \mathrm{AS}$ & + & + & + & 0 & + \\
\hline \#switches 2004 & & & & - & 0 & - \\
\hline \multirow[t]{4}{*}{$S n *>S n$} & $\mathrm{AS} \rightarrow \mathrm{FS}$ & 0 & 0 & 0 & 0 & 0 \\
\hline & $\mathrm{AS} \rightarrow \mathrm{AS}$ & 0 & 0 & 0 & 0 & 0 \\
\hline & $\mathrm{FS} \rightarrow \mathrm{FS}$ & - & 0 & - & 0 & - \\
\hline & $\mathrm{FS} \rightarrow \mathrm{AS}$ & 0 & 0 & 0 & 0 & 0 \\
\hline \#switches 2004 & & & & + & 0 & + \\
\hline \multirow[t]{4}{*}{$S n *<S n$} & $\mathrm{AS} \rightarrow \mathrm{FS}$ & 0 & 0 & 0 & 0 & 0 \\
\hline & $\mathrm{AS} \rightarrow \mathrm{AS}$ & 0 & 0 & 0 & 0 & 0 \\
\hline & $\mathrm{FS} \rightarrow \mathrm{FS}$ & 0 & 0 & 0 & - & - \\
\hline & $\mathrm{FS} \rightarrow \mathrm{AS}$ & 0 & 0 & 0 & 0 & 0 \\
\hline \#switches 2004 & & & & 0 & + & + \\
\hline Total & & & & & & \\
\hline \#switches 2004 & & & & & & + \\
\hline
\end{tabular}

$I T S_{\text {current }}^{\Delta \text { fund }}$ : difference between the value of current pension rights when a switch takes place to a job with a different pension fund and the value of current pension rights when not switching jobs. IT $S_{\text {future }}^{\Delta \text { fund }}$ : difference between the value of future pension rights when a switch takes place to a job with a different pension fund and the value of future pension rights when not switching jobs. ITS $S^{\Delta \text { fund: }}$ summation of $I T S_{\text {current }}^{\Delta \text { fund }}$ and $I T S_{\text {future }}^{\Delta \text { fund }} I T S_{\text {current }}^{\text {samefund }}$ : difference between the value of current pension rights when a switch takes place to a job with the same pension fund and the value of current pension rights when not switching jobs. IT $S^{\text {total }}$ : summation of $I T S^{\Delta f u n d}$ and IT $S_{\text {current }}^{\text {samefund }}$. AS: average salary pension scheme. FS: final salary pension scheme. $w$ : yearly wage increase. $r$ : valorisation rate of accrued pension wealth. $S n$ : salary in the current job. $S n *$ : salary when accepting a new job.

Note: Predicted effects from the pension system reforms in 2004 are given in gray, - implies negative incentive to switch jobs, + implies a positive incentive to switch jobs. 
Hypothesis 3: Job switches (to an employer with a different pension fund) with individuals experiencing a promotion $\left(S_{n}^{*}>S_{n}\right)$ are more likely to occur when their current pension plan is of the DB-average-salary form.

An individual covered by a DB-final-salary-plan who experiences a promotion when switching to an employer with another final salary plan loses part of his accrued pension rights when making the switch. For all other transitions (final-average or average-final or average-average) such problems do not arise.

Hypothesis 4: Job switches (to an employer with the same pension fund) with individuals experiencing a demotion $\left(S_{n}^{*}<S_{n}\right)$ are more likely to occur when their current pension plan is of the DB-average-salary form.

An individual covered by a DB-final-salary-plan who experiences a demotion when switching to an employer who is covered by the same pension plan loses part of his accrued pension rights when making the switch. Individuals are therefore less likely to accept a demotion when they are covered by a final-salary pension fund.

Hypothesis 5: On aggregate, individuals are more likely to switch jobs when their current pension plan is of the DB-average-salary-form.

As the majority of the theoretical effects points in the direction of an increase in job switches we expect aggregate job-to-job flows to increase. One can think of circumstances in which the expected number of job-to-job flows will decrease, for example, when there are many individuals for whom $w<r$. However, since the valorisation $r$ is never higher and often lower than the average salary rise in a sector, this situation is irrelevant empirically.

\section{Data}

We make use of administrative data obtained from Statistics Netherlands. The so-called Social Statistical Files 1999-2008 data is obtained from municipalities, tax authorities and social insurance administrations. It contains high quality, detailed information on beginning- and enddate of wage payments for all individuals living in the Netherlands. It also provides information on characteristics of the job an individual is working in, such as the wage paid, whether the individual is in fulltime or parttime employment, and the number of days worked in a job every year. Data on the exact occupation is unknown, but the data does contain the sectoral code of the employer with up to 5-digit precision. Since many pension funds in the Netherlands are sector-specific, a number of pension funds can be linked to the sectoral codes using the information in collective labour agreements. ${ }^{15}$ Linking pension funds to sectoral codes was not possible for all pension funds,

\footnotetext{
${ }^{15}$ A similar procedure is used by Euwals et. al. (2010). The collective labour agreements can be found on www.caoweb.nl and contain direct information on the sector code to which the agreement applies. Apart from using the sectoral codes to identify the employees covered by ABP or PGGM, a cross-validation was carried out for ABP using an indicator for being employed by the government available from the data. A cross-validation for PGGM was carried out by merging our dataset with a datafile acquired from PGGM that lists participants in the pension fund on the 1st of January each year. For both ABP and PGGM,
} 
including those that are company-specific instead of sector-specific. In addition, some sectors are served by multiple pension funds, and some industries do not have a compulsory pension fund, making it impossible to link a job to a specific pension fund. Apart from the pension funds for civil servants and the health care sectors, we select all identifiable pension funds that offered a DB-average-salary plan throughout the years 1999-2008. These 14 pension funds will form the control group in the empirical difference-in-difference estimation. The pension fund for civil servants and the pension fund for the health sector offered a finalsalary scheme in 1999, but in 2004 changed to an average-salary scheme. They therefore form the treatment groups. The selected pension funds are listed in Table 4. For these funds, we track individuals from the age of 25. This was the legal maximum age at which pension accrual is supposed to start (as from 2007, this maximum age was reduced to 21). We follow an individual until he/she reaches the age of 55, such that our analysis is not affected by retirement decisions. In 2004, 27 percent of Dutch employees retired before the age of 60 (CBS, 2016).

We follow Royalty (1998) and label as job-to-job transitions only those transitions in which the next job starts within 1 month (31 days) after the current job ends. ${ }^{16}$ The choice of this relatively short time interval has several advantages. First, we can be sure that there is no long-lasting spell of unemployment, sickness or disability in between the two jobs. Although the possibility to transfer any accrued pension rights to the new employer is not compromised by an intervening spell of unemployment or disability, it seems unlikely that individuals that have been unemployed for some time are paying much attention to pension arrangements in their search for a new job. Second, confining the maximum interval between jobs to 1 month makes it more likely that the transitions we observe are voluntary, such that the analysis is not contaminated by the inclusion of layoffs. ${ }^{17}$ Results of Section 2 are not affected by considering all jobs that start within 2 months after the current job ends as job-to-job transitions.

For the analysis, we only select the years 1999-2004: years 1999-2003 pre-reform and year 2004 postreform. From 2005-2008, there are various data issues concerning the number of jobs according to sector in the Social Statistical Files. In 2005, part of the jobs in agriculture and the construction industry are missing from the data. Between 2005/2006 and 2006/2007 Statistics Netherlands advises not to publish the number of jobs per sector on a detailed level because of a number of deviations from the trend in those years.

the use of the sectoral SBI indicator had a near-complete matching ( $>98 \%$ for ABP and $>90 \%$ for PGGM) with the other indicators - strengthening confidence in the identification of the members of various pension funds using sectoral indicators.

${ }^{16}$ We also consider as job-job transitions all spells in which the next job starts at most 1 month before the current job ends. In this case, the next job should also continue for at least 1 month after the current job ends. This way we allow for a possible small overlap between subsequent jobs.

${ }^{17}$ Reorganisations within the government or health care sector are also picked up as transitions whenever the reorganisation means that one job contract is closed and another one is signed. This might affect the number of within-government or health care transitions observed. The data-analysis therefore uses a multinomial logit model to separate between within-sector and between-sector movements. We are not aware of any large government or health care reorganisations taking place in the period studied. 
Table 4. OVERVIEW OF PENSION FUNDS INCLUDED IN THE SAMPLE

\begin{tabular}{|c|c|c|}
\hline Pension fund & SBI '93 & Description \\
\hline \multirow[t]{2}{*}{$\mathrm{ABP}$} & $75($ not $753,7513,7522)$ & civil servants \\
\hline & $80($ not 8042$)$ & education \\
\hline PGGM & $85^{*}$ & health care \\
\hline $\mathrm{BPD}$ & $159($ not 1596,1597$)$ & beverages industry \\
\hline BPSG & 7470 & (window-)cleaning industry \\
\hline GBF & 222 & graphic industry \\
\hline $\mathrm{GF}$ & 153 & vegetable and fruit industry \\
\hline $\mathrm{PK}$ & 93021 & haircutters \\
\hline BPL & $011-016,1571$ & agriculture \\
\hline PMT & $285,342,362,453$ & metal industry \\
\hline BPSAG & 4544 & construction industry \\
\hline PS & 52221 & butchers \\
\hline $\mathrm{PT}$ & 33101 & dental care \\
\hline PBVD & 2430 & paint industry \\
\hline VLEP & 15132,5132 & meat industry \\
\hline SFW & 4524 & hydraulic engineering industry \\
\hline PW & $52441,52442,52444,52465,52466$ & furniture industry \\
\hline $\begin{array}{l}\text { *Note: excluded } \\
85152,85153,85 \\
\text { by a profession-s } \\
\text { For ABP, code } 7 \\
\text { place. }\end{array}$ & $\begin{array}{l}\text { om PGGM are: } 851111,85121,85122 \text {, } \\
8517,8520,85329,85331,85342,85344 \text {. } \\
\text { cific funds, such as GP's, specialists, birt } \\
2 \text { denotes te military, for whom the switcl }\end{array}$ & $\begin{array}{l}513,85141,85142,85145,85146,85151 \text {, } \\
\text { his mainly exludes those who are covered } \\
\text { attendants, dentists, and veterinarians. } \\
\text { from final to average-salary did not take }\end{array}$ \\
\hline
\end{tabular}

\subsection{Descriptive Statistics}

Table 5 shows background characteristics of individuals included in the control group, ABP (civil servants) and PGGM (health care sector) samples. As can be seen from the Table, the selected ABP-employed individuals are on average slightly older and earn more than those working in one of the control sectors. The health care sector covered by PGGM has a much larger percentage of female workers and, accordingly, more parttime workers than the sectors representing the control group. Both employees working as civil servants and health care workers are on average more highly educated than those working in the control group sector.

The common trend assumption is the key identifying assumption of the difference-in-difference estimation in Section 5. This involves that in case the final salary to average salary change would not have taken place, the trend in the fraction of yearly job switches in the government (health care) sector would have been the same as the trend in the control group. The top left panel of Figure 2 shows that in the years 1999-2003, 


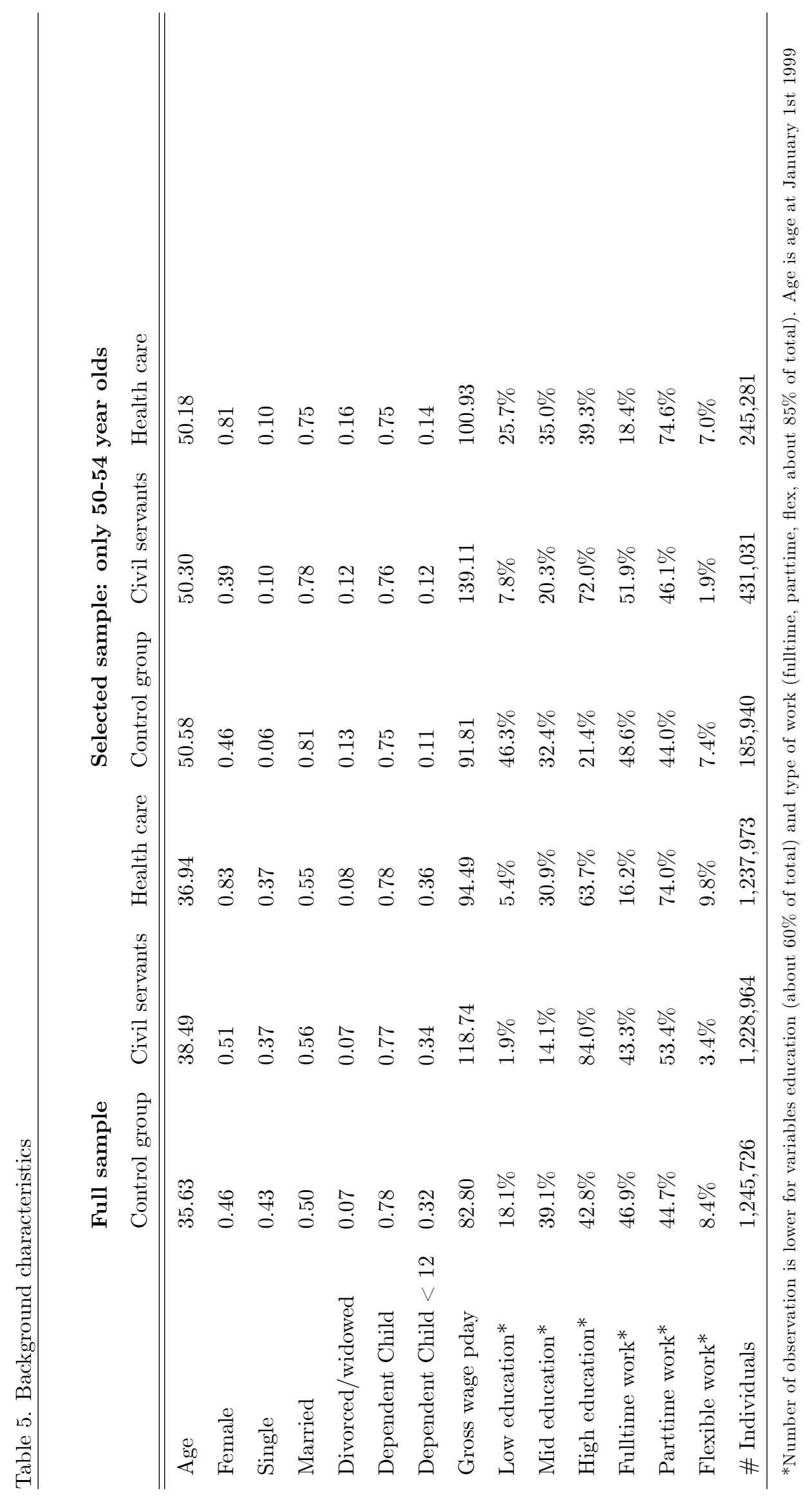



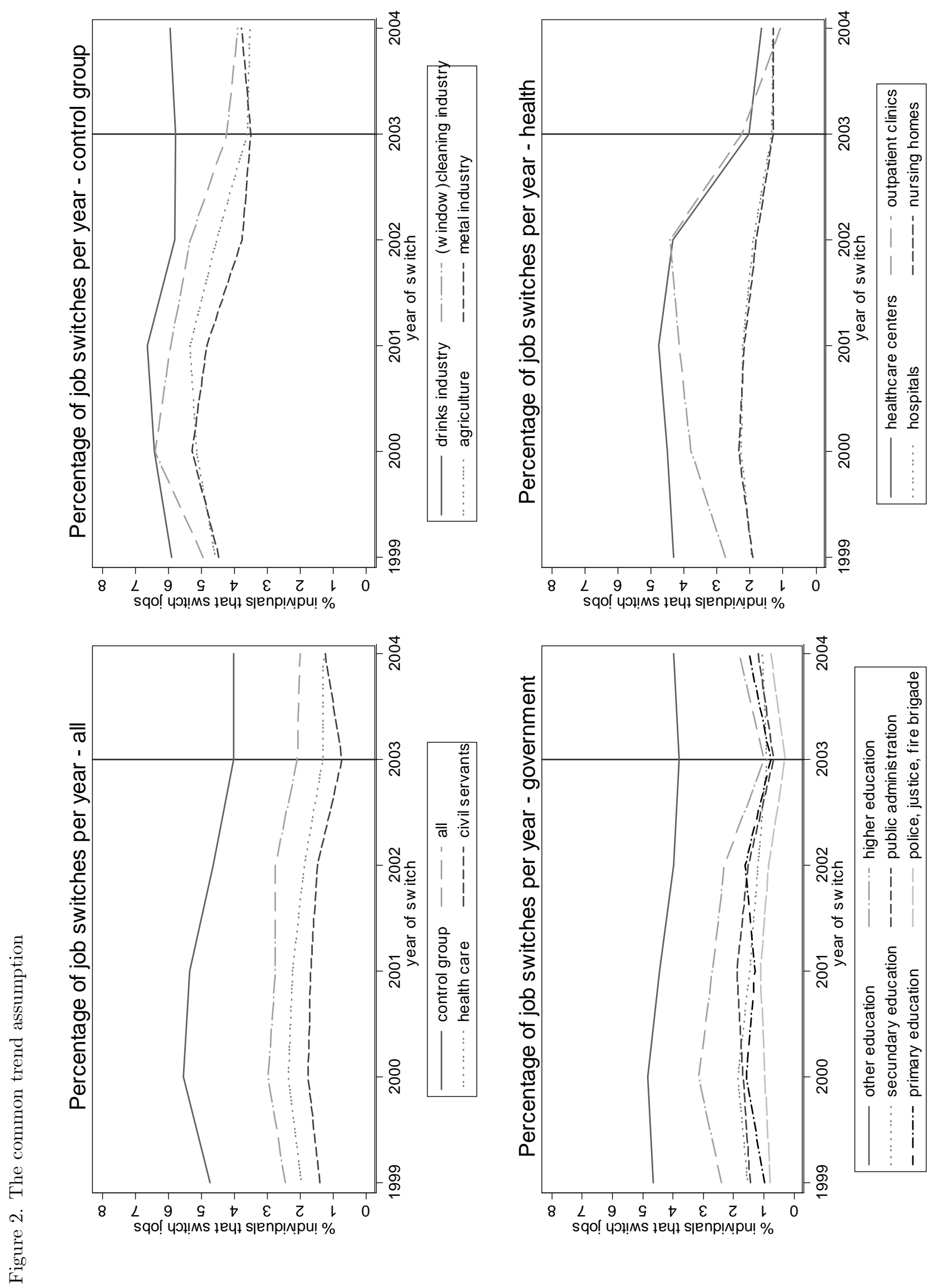
Figure 3. Number of civil servants increasing from 1999-2004

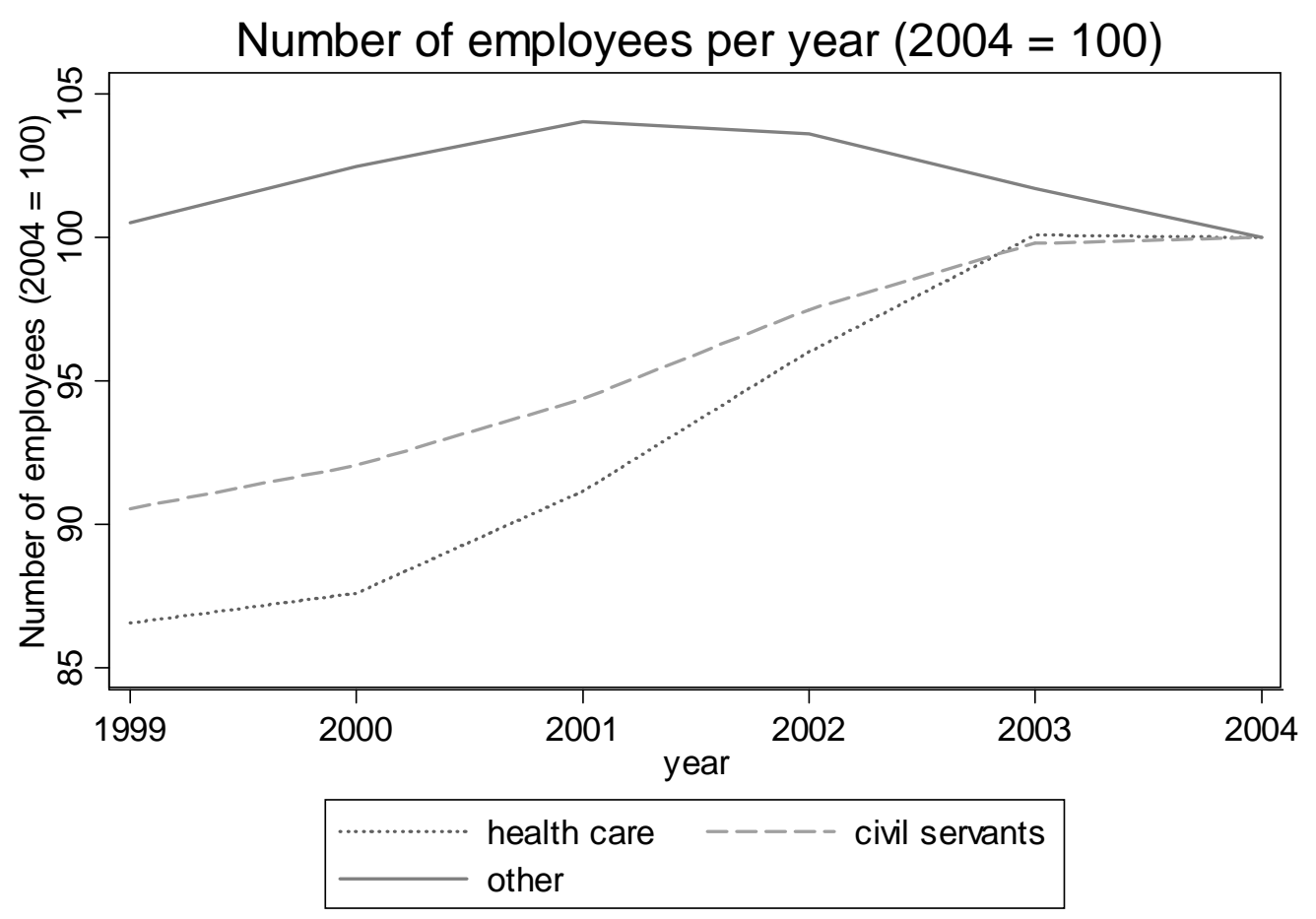

the percentage of job transitions for the control group and the two treatment groups follow a very similar pattern. In fact, the fluctuations in the propensity to change jobs from 1999-2003 for each group is very similar to that of the aggregate economy (excluding ABP and PGGM), providing confidence that sectoralspecific issues do not differentially influence job transition behaviour in this period. The Figure also shows that the percentage of job-to-job transitions is increasing for civil servants, but not for the control group (hypothesis 5 - an overall increase in the propensity to switch jobs). However, there also seems to be a small anticipation effect for civil servants: the percentage of job transitions in 2003 decreases relatively more for civil servants than for the control group. In the regression analysis in Section 5 we therefore do not take the year 2003 as a baseline, but all years 1999-2003. Taking 2003 as a baseline results in slightly larger estimates than the ones presented in Section 5 for civil servants, excluding 2003 as a baseline results in slightly smaller estimates. Figure 2 does not show an increase in the percentage of job-to-job transitions for those working in the health care sector.

The increase in the fraction of job switches from jobs in the public sector in 2004 is not mimicked by a general decline in the number of employees in the public sector (as would be the case if - for example - a budget cut in the public sector would have taken place). Figure 3 shows that in fact, the number of employees in both the health care and the public sector stays constant whereas the number of employees in other sectors is decreasing in 2004 (and 2003).

The top right panel of Figure 2 shows that between the four largest sectors of the control group, there 
are no large differences in the patterns of job switches over the years. The (window)cleaning industry has a slightly higher increase in the percentage of job switchers in 2000 as compared to the other sectors. The change in the percentage of switches from 2003 to 2004 is slightly positive or slightly negative for all sectors in the control group. For the various types of civil servants (down left panel) we see an increase in the percentage of job switches from 2003 to 2004 for everyone except those working in 'other educational jobs' (not primary, secondary or higher education). For the health care sector (down right panel) we see either a slight increase or a slight decrease in the percentage of job transitions from 2003 to 2004, comparable to those in the control group. However, in outpatient clinics the percentage of job transitions is clearly decreasing in 2004. In a sensitivity analysis of our estimations in Section 5 we will estimate the effects of the change in pension scheme in 2004 separately for the various types of civil servants and health care professionals depicted in Figure 2.

Table 6 provides some detailed information on the percentage and type of job-to-job transitions made by members of treatment and control group in the years 1999-2004. The first summary statistic - the percentage of individuals switching jobs - shows the exact figures underlying Figure 2. The percentage of individuals switching jobs is indeed increasing for civil servants (hypothesis 5).

We also expect those with a high expected wage increase in their new job $(w>r)$ to change jobs more often in 2004 (hypothesis 1 and 2). However, the percentage of job switches which involves individuals with a high actual wage increase in their new job actually decreases for civil servants. ${ }^{18}$ An individual is considered to have $w>r$ when their wage growth in the new job is larger than $r(0.3 \%) .{ }^{19}$

We also expect those who make a promotion to switch more often to a job with a different pension fund, and those who make a demotion to switch more often to jobs with the same pension fund (hypothesis 3 and 4). However, while the percentage of job switches with the same pension fund which involves a demotion is indeed increasing for both civil servants and health care professionals, this is not true for the percentage of job switches with a different pension fund which involve a promotion. In 2004, a higher percentage of accepted wages is below the wage in the old job: moving from a final salary system to an average salary system decreases transaction costs of individuals, thereby decreasing the reservation wage (van den Berg, 1992) which puts a downward pressure on the distribution of accepted wages. An individual is considered to make a promotion when the real daily wage in the new job in period $t$ is higher than the real daily wage in the old job in period t-1.

The descriptives do not control for a possible general trend in decreasing relative wages for those (formerly) in the government and health care sector. The descriptives also do not control for a possible correlation between a promotion at the time of switching jobs (higher wage in new job as compared to old job) and a high wage increase in the new job. In the estimation in Section 5 we will control for these various possible

\footnotetext{
18 A possible explanation may be that the switch from the final wage to the average wage system decreased reservation wages such that workers were willing to switch jobs at lower wages in the destination job.

19 In the period 1999-2003, the average real wage increase which was laid down in collective labour agreements was $0.3 \%$ per year.
} 
Table 6. Switches and wage growth/promotion in new job

\begin{tabular}{|c|c|c|c|c|c|c|}
\hline & 1999 & 2000 & 2001 & 2002 & 2003 & 2004 \\
\hline \multicolumn{7}{|l|}{$\%$ switching } \\
\hline Control group & 4.7 & 5.5 & 5.4 & 4.7 & 4.0 & 4.0 \\
\hline Civil servants & 1.4 & 1.8 & 1.7 & 1.5 & 0.7 & 1.3 \\
\hline Health care & 2.0 & 2.4 & 2.2 & 1.9 & 1.3 & 1.3 \\
\hline \multicolumn{7}{|c|}{$\%$ of switches with $w>r$ in new job } \\
\hline Control group & 59.9 & 66.3 & 64.9 & 60.5 & 54.5 & 56.7 \\
\hline Civil servants & 58.7 & 63.0 & 71.5 & 59.0 & 70.3 & 62.7 \\
\hline Health care & 49.8 & 57.5 & 55.8 & 54.1 & 43.2 & 43.9 \\
\hline \multicolumn{7}{|c|}{ median wage increase in new job (percentage points) } \\
\hline Control group & 7.0 & 12.0 & 11.4 & 7.2 & 3.8 & 5.0 \\
\hline Civil servants & 6.8 & 10.5 & 15.9 & 5.8 & 16.8 & 9.9 \\
\hline Health care & 0.2 & 6.7 & 5.0 & 4.1 & -5.7 & -5.0 \\
\hline \multicolumn{7}{|c|}{$\%$ of switches to same pension fund } \\
\hline Control group & 12.3 & 13.8 & 12.0 & 13.8 & 15.6 & 17.0 \\
\hline Civil servants & 15.8 & 20.3 & 15.0 & 24.4 & 33.4 & 28.1 \\
\hline Health care & 16.2 & 17.9 & 17.3 & 17.6 & 20.7 & 21.6 \\
\hline \multicolumn{7}{|c|}{ of switches to same pension fund: \% promotion } \\
\hline Control group & 37.4 & 42.8 & 44.7 & 45.1 & 39.6 & 38.5 \\
\hline Civil servants & 26.5 & 34.4 & 46.1 & 36.9 & 39.0 & 30.8 \\
\hline Health care & 35.3 & 38.5 & 40.7 & 38.9 & 39.0 & 34.6 \\
\hline \multicolumn{7}{|c|}{$\%$ of switches to different pension fund } \\
\hline Control group & 87.7 & 86.2 & 88.0 & 86.2 & 84.4 & 83.0 \\
\hline Civil servants & 84.2 & 79.7 & 85.0 & 75.6 & 66.6 & 71.9 \\
\hline Health care & 83.8 & 82.1 & 82.7 & 82.4 & 79.3 & 78.4 \\
\hline \multicolumn{7}{|c|}{ of switches to different pension fund: \% promotion } \\
\hline Control group & 40.0 & 43.1 & 44.4 & 40.2 & 39.0 & 40.4 \\
\hline Civil servants & 38.5 & 43.0 & 46.9 & 38.9 & 56.0 & 46.3 \\
\hline Health care & 32.5 & 36.8 & 35.7 & 36.9 & 32.8 & 32.2 \\
\hline
\end{tabular}

An individual is considered to make a promotion whenever the real daily wage in the new job in the year of switching is higher than the real daily wage in the old job. An individual is considered to have $w>r$ whenever the real daily wage increase in the new job from the year of switch $\mathrm{t}$ to $\mathrm{t}+1$ is higher than $0.3 \%$ (the average real yearly wage increase pinned down in collective labour agreements in the period 1999-2003). 
confounding factors.

An advantage of using individuals that are employed in a different sector of industry as a control group, is that only a tiny fraction of individuals move between these sectors. If substitution between the treatment and control sectors were large, a decrease in the attractiveness of pension system for the treatment group could induce a lower number of job transitions in the control group, thereby overestimating the treatment effect. Table 7 shows that only 2 percent of the job switchers in our control group switch jobs to the health care or government sector. Further, the fraction of individuals that switch to a job which is covered by the same pension fund increases in 2004 for all groups.

Table 7. Fraction of individuals switching between pension funds

Before 2004 (1999-2003)

\begin{tabular}{llllll}
\hline & \multicolumn{3}{c}{ New pension fund } \\
& $\begin{array}{l}\text { Control } \\
\text { group }\end{array}$ & $\begin{array}{l}\text { Civil } \\
\text { servants }\end{array}$ & $\begin{array}{l}\text { Health } \\
\text { care }\end{array}$ & Other & Total \\
\hline \hline \multicolumn{1}{c}{ Old pension fund } & & & & & \\
Control group & 0.13 & 0.01 & 0.01 & 0.85 & 1.00 \\
Civil servants & 0.01 & 0.20 & 0.02 & 0.76 & 1.00 \\
Health care & 0.03 & 0.02 & 0.18 & 0.77 & 1.00 \\
\hline
\end{tabular}

In 2004

\begin{tabular}{llllll}
\hline & \multicolumn{3}{c}{ New pension fund } \\
& $\begin{array}{l}\text { Control } \\
\text { group }\end{array}$ & $\begin{array}{l}\text { Civil } \\
\text { servants }\end{array}$ & $\begin{array}{l}\text { Health } \\
\text { care }\end{array}$ & Other & Total \\
\hline \hline \multicolumn{1}{c}{ Old pension fund } & & & & & \\
Control group & 0.17 & 0.01 & 0.01 & 0.81 & 1.00 \\
Civil servants & 0.01 & 0.28 & 0.02 & 0.69 & 1.00 \\
Health care & 0.03 & 0.02 & 0.22 & 0.73 & 1.00 \\
\hline
\end{tabular}

\subsection{Correlations Between Pension Type and Job Transition Probabilities}

The Social Statistical Files do not contain direct information on the type of pension scheme offered to the workers. However, we can show some interesting correlations between the type of pension scheme and the percentage of individuals that change employer using a different dataset, listing for each individual the pension scheme offered on December 31st 2005. This dataset is also available from Statistics Netherlands. Since the dataset only measures pension participation on December 31st 2005, it will not be used for analysis 
of the natural experiment, which took place in 2004. Merging this dataset to the Social Statistical Files makes it possible to identify the pension scheme for every individual with exactly one job on December 31st 2005, and record any job changes up to December 31st 2008. Table 8 shows the percentage of individuals experiencing a transition from a DB or a DC pension plan job, respectively. There is a striking positive correlation between being covered by a DC plan and the propensity to switch jobs. Table 8 also shows that also for DB-plans the propensity to switch jobs has a clear ranking. From highest to lowest: individuals with a non-indexed average-salary scheme, an indexed average-salary scheme or a moderated final-salary scheme, and a pure final-salary scheme. When transferability of pension rights matters, this is exactly what we would expect to see. A DC plan creates no incentive to stay with the current employer as a means to retain pension rights, whereas the loss of pension rights inherent in a DB-final-salary plan keeps employees from switching jobs. However, the found correlation can not be interpreted as a causal effect of intransferable pension rights, as it might be that sectors with a high job turnover are more likely to offer a DC pension plan.

Table 8. Percentage that switch jobs by type of pension scheme

\begin{tabular}{lccc} 
& 2006 & 2007 & 2008 \\
\hline \hline \% switching from Defined Benefit, & Defined & Contribution & \\
Defined Contribution & 12.6 & 13.4 & 9.0 \\
Defined Benefit & 7.5 & 10.0 & 6.1 \\
\% switching from Final Salary, Average Salary & \\
Non-indexed Average Salary & 13.8 & 15.0 & 9.4 \\
Indexed Average Salary & 7.8 & 11.2 & 6.7 \\
Moderated Final Salary & 8.5 & 10.5 & 5.9 \\
Pure Final Salary & 5.3 & 8.3 & 6.4 \\
\hline
\end{tabular}

\section{Estimation Results}

In this Section we will test the hypotheses laid down in the theory in Section 3.

\subsection{Modelling probabilities}

All hypothesis are tested using (multinomial) logit regressions. In these models, the yearly probability to switch to another job is given as:

$$
\operatorname{Prob}\left(Y_{i}=j\right)=\frac{e^{\beta_{j}^{\prime} x_{i}}}{\sum_{k=0}^{K} e^{\beta_{k}^{\prime} x_{i}}}
$$


Here, $\beta_{0}$ is normalized to 0 . We have $K=1$ for the binary logit model that we use to model the probability of a job-to-job transition. This enables testing Hypothesis 5 . Among the regressors $x_{i}$, treatment is included as the variable of interest, which is an interaction effect between the treatment year 2004 and a dummy for the treated pension fund. We also add the dummy for the treated pension fund and the year 2004 separately. We use the years 1999-2003 as our baseline. As additional regressors we include dummy variables for being female, for being married or widowed (as opposed to being single), for having a child in the household and for having a young child in the household ( $<12$ years old). We also control for the unemployment rate per year. From the coefficient on the interaction term of the dummy for the treated pension fund and the dummy for the year 2004 we compute the treatment effect as the percentage point change (due to treatment) in the yearly fraction of job transitions for the treated. Standard errors are calculated using the delta method.

The multinomial logit models serve to further refine our analysis of treatment. First, when a change in pension rules is truly driving the job decision of individuals, we would expect that especially the number of transitions to a sector outside the domain of the old pension fund is increased at the time of the policy change. In the first multinomial logit model below, we therefore identify two exit states $(K=2$ in (13)): (1) a switch to a job covered by the same pension fund and (2) a switch to a job covered by a different pension fund.

Second, we would expect that especially the number of transitions for career-making individuals increased at the time of the policy change, allowing to test Hypotheses 1 through 4 . In the second multinomial logit model below, we therefore identify four different states $(K=3)$ : $(1)$ no switch and promotion $(w>r)$, (2) no switch and demotion $(w<r)$, (3) switch and promotion $\left(S_{n}^{*}>S_{n}\right)$ and $(4)$ switch and demotion $\left(S_{n}^{*}<S_{n}\right)$. Hypotheses 1 through 4 say that the treatment effect of outcome (1) is positive, that of outcome (2) is negative, while those of outcomes (3) and (4) are positive again. ${ }^{20}$

\subsection{A General Increase in the Percentage of Job Switches}

Using binary logit and multinomial logit models, we can test whether pension coverage by a system that induces less capital losses upon a change of jobs will lead to a higher number of job transitions: Hypothesis 5: On aggregate, individuals are more likely to switch jobs when their current pension plan is of the DBaverage-salary-form.

Results from the logit estimates are given in Table 9. The models are estimated for the full sample (first line), and separately for each five-year age group in order to account for the differences in job transition behaviour of younger and older employees. Here it is shown that for health care professionals, covered by pension fund PGGM, the percentage of job switches did change slightly in following the transition from a DB-final salary to a DB-average salary system. The effect is only significant for the full sample. Pension fund ABP for civil servants experienced a large increase in the percentage of job transitions, for all age categories.

\footnotetext{
${ }^{20}$ Since probabilities add-up to 1 , the hypotheses cannot have all have the same sign for the treatment effect, which is satisfied here.
} 
Table 9. Baseline results - logit estimates

PGGM-Health care

\begin{tabular}{lllllll} 
Age & Treatment & From & To & Treatment & From & To \\
\hline \hline $25-54$ & $0.08^{* * *}$ & 1.23 & 1.30 & $0.61^{* * *}$ & 0.64 & 1.25 \\
$25-29$ & 0.09 & 2.27 & 2.36 & $1.34^{* * *}$ & 1.21 & 2.55 \\
$30-34$ & 0.04 & 1.37 & 1.41 & $0.78^{* * *}$ & 0.63 & 1.42 \\
$35-39$ & 0.08 & 0.98 & 1.06 & $0.44^{* * *}$ & 0.52 & 0.96 \\
$40-44$ & 0.06 & 0.83 & 0.89 & $0.42^{* * *}$ & 0.43 & 0.86 \\
$45-49$ & 0.06 & 0.67 & 0.73 & $0.28^{* * *}$ & 0.43 & 0.71 \\
$50-54$ & 0.07 & 0.48 & 0.55 & $0.26^{* * *}$ & 0.33 & 0.59 \\
\hline
\end{tabular}

Average treatment effects are percentage point changes in the yearly fraction of job transitions for the treated $* * *, * *, *$ indicate significance at $1 \%, 5 \%$ and $10 \%$ level respectively

Table 10 shows that virtually all of these increased transitions are transitions to jobs not covered by the old pension fund. For individuals aged 25-29 and 30-34 we also see that transitions between employers that both offer an ABP pension almost doubled. The higher rise in transitions for younger age groups may be consistent with Hypothesis 1, since especially the younger workers may expect to experience further wage growth during their career. The increase in job transitions in terms of percentage points is quite small. However, the increase relative to the baseline is large: for most age groups job mobility almost doubles when going from a DB-final salary to a DB-average salary pension plan.

We perform several sensitivity analyses. First we include a dummy for the year 2003, using only the years 1999-2002 as a baseline. Second, we include a dummy for the years 1999, 2000, 2001 and 2002 using only the year 2003 as a baseline. Third we included education dummies as regressors in the equations. Fourth, we included random effects in the logit estimation. In all alternative specifications, the significance of the estimates remains. Moreover, there is no sign of differential treatment effects for males versus females, high versus low educated, or those working fulltime or parttime. When estimating differential treatment effects for various subsectors of civil servants (primary education, secondary education, public administration etc.), all subsectors show significantly positive results. For subsectors health care centers and outpatient clinics, treatment effects are (significantly) negative. Those working in health care centers are typically GP's and other medical specialists in primary care. GP's and many other specialists in primary care are not covered by PGGM and therefore not affected by the policy change. 
Table 10. Baseline results - multinomial logit estimates

PGGM-Health care

To a different pension fund

To PGGM

\begin{tabular}{cllllll}
\hline Age & Treatment & From & To & Treatment & From & To \\
\hline \hline $25-54$ & $0.06^{* *}$ & 0.97 & 1.02 & 0.02 & 0.26 & 0.28 \\
$25-29$ & 0.10 & 1.84 & 1.93 & 0.00 & 0.42 & 0.42 \\
$30-34$ & 0.02 & 1.12 & 1.14 & 0.04 & 0.23 & 0.27 \\
$35-39$ & 0.05 & 0.78 & 0.83 & 0.03 & 0.20 & 0.23 \\
$40-44$ & 0.04 & 0.62 & 0.66 & 0.01 & 0.22 & 0.22 \\
$45-49$ & 0.05 & 0.50 & 0.55 & -0.00 & 0.18 & 0.18 \\
$50-54$ & $0.06^{*}$ & 0.33 & 0.39 & -0.01 & 0.16 & 0.15 \\
\hline
\end{tabular}

\section{ABP-Civil servants}

To a different pension fund

To ABP

\begin{tabular}{rllllll}
\hline Age & Treatment & From & To & Treatment & From & To \\
\hline \hline $25-54$ & $0.50^{* * *}$ & 0.40 & 0.90 & $0.08^{* * *}$ & 0.27 & 0.35 \\
$25-29$ & $1.06^{* * *}$ & 0.96 & 2.02 & $0.27^{* * *}$ & 0.25 & 0.53 \\
$30-34$ & $0.65^{* * *}$ & 0.47 & 1.12 & $0.12^{* * *}$ & 0.17 & 0.29 \\
$35-39$ & $0.34^{* * *}$ & 0.33 & 0.68 & 0.05 & 0.23 & 0.28 \\
$40-44$ & $0.32^{* * *}$ & 0.24 & 0.56 & $0.06^{*}$ & 0.24 & 0.29 \\
$45-49$ & $0.24^{* * *}$ & 0.20 & 0.45 & -0.02 & 0.29 & 0.26 \\
$50-54$ & $0.23^{* * *}$ & 0.14 & 0.36 & -0.04 & 0.27 & 0.22 \\
\hline
\end{tabular}

Treatment effects are percentage point changes in the yearly fraction of job transitions for the treated

$* * *, * *, *$ indicate significance at $1 \%, 5 \%$ and $10 \%$ level respectively

\subsection{Differential Effects for Those Experiencing Promotion, Demotion, $w>r$ or} $w<r$

Because the effects of a policy change that constitutes a switch from a final-salary to an average-salary system are predicted to be heterogeneous, we continue by estimating a multinomial logit model with as states: (1) no switch and promotion, (2) no switch and demotion (3) switch and promotion $\left(S_{n}^{*}>S_{n}\right)$ and (4) switch and demotion $\left(S_{n}^{*}<S_{n}\right)$.

Hypotheses 3 and 4: Job switches (to an employer with a different pension fund) with individuals experiencing a promotion are more likely to occur when their current pension plan is of the DB-average-salary form. Job switches (to an employer with the same pension fund) with individuals experiencing a demotion 
are more likely to occur when their current pension plan is of the DB-average-salary form.

In the data, an individual is considered to make a promotion when the real daily wage in the new job in period is higher than the real daily wage in the old job in period. For those years in which the individual does not switch jobs, an individual is considered to make a promotion when the real daily wage in the old job in period $t$ is higher than the real daily wage in the old job in period. Because we use information from period in the estimation and our data run from 1999-2005, job switches in the year 1999 are not included in these estimations.

Another source of heterogeneity in effects may be important. Those with high expected wage rises are expected to switch jobs more easily, whereas for those with low expected wage rises the percentage of job switches should decrease:

Hypotheses 1 and 2: Individuals with high expected wage increases $(w>r)$ are more likely to switch jobs, whereas those with low expected wage increases $(w<r)$ are less likely to switch jobs when their current pension plan is of the DB-average-salary form.

Since we use administrative data, expected wage increases cannot be measured directly. We use the actual wage increase in the new job as a proxy for the expected wage increase. For those years in which the individual switches jobs, wage growth $w$ is determined by taking the real daily wage in year $\mathrm{t}$ and $\mathrm{t}+1$ in the new job and calculating wage growth. Whenever this number is higher than $r(0.3 \%)$ the individual is considered to have a high expected wage increase $(w>r)$. For those years in which the individual does not switch jobs, wage growth $w$ is determined by taking the real daily wage in year $\mathrm{t}$ and year $\mathrm{t}+1$ in the old job and calculating wage growth.

There is potentially a correlation between future wage rises in the new job $(w>r)$ with the experience of promotion or demotion at the moment the transition is made. We therefore include extra interactions in the model and test hypothesis 1, 2, 3 and 4 simultaneously. The extra regressors we include are: (1) an indicator when $w>r(2)$ an interaction of the indicator $w>r$ with a dummy for the treated pension fund (3) an interaction of the indicator $w>r$ with a dummy for the year 2004 and (4) an interaction of the indicator $w>r$ with a dummy for the treated pension fund and the year 2004 .

It is likely that those with high (expected) wage increases are more prone to switch jobs, even in the absence of any pension rule changes. However, there is no reason to believe that this selection effect is especially strong for individuals working at ABP/PGGM in the year 2004, and not in other years or for those working in other sectors. In other words, our dif-in-dif framework controls for a possible positive correlation between (expected) wage increases and switching probability (assuming a common trend on a possible selection effect as well).

Wage growth is not observed for all individuals. In fact, almost all individuals for whom wage growth is observed either do not change jobs or change to a job with a different pension fund. The estimation results in Table 11 and Table 12 should therefore be interpreted as the effect of a switch from a DB-final-salary to DB-average-salary pension scheme on the propensity to switch to a job which is covered by a different 
pension fund. Hypothesis 4 (higher propensity to switch to a job covered by same pension fund for those experiencing a demotion) is therefore not tested in these estimations. We expect the propensity to switch to a job covered by another pension fund either not to change for those who experience a demotion, or to decrease since more individuals will opt for a new job covered by the same pension fund. However, both for civil servants (Table 12) and health care professionals (Table 11) the number of switches to a different pension fund for those experiencing demotion actually increases. Moreover, the number of health care professionals experiencing a promotion decreases, whereas for civil servants there seems to be a rise in the number of switches with promotion matching the number of switches with demotion. These results are not in line with hypothesis 3 . For both civil servants and health care professionals, hypotheses 1 and 2 are also not confirmed by the estimation results. For health care professionals, the difference in propensity to switch jobs seems much more driven by making either a promotion or demotion, than with actual wage increase in the new job. For civil servants, the relative change from the baseline percentage of switches is about the same for those who have $w>r$ and for those who have $w<r$. The increase in the number of job switches by civil servants and health care professionals in 2004 can therefore not be explained by the financial incentives caused by the change in pension rules. In principle, the fact that we observe an increase not only in the number of promotions but also in the number of demotions could be driven by general equilibrium effects of the lower costs of turnover embedded in the DB-salary system. First, lower transaction costs puts downward pressure on the reservation wage (van den Berg, 1992) thereby decreasing accepted wages of civil servants and health care professionals. Second, lower transaction costs may induce employers of civil servants and health care professionals to pay a higher wage in order to retain their most valuable workers, who therefore are not observed to switch jobs. Indeed, the multinomial logit estimates show an increase in the number of promotions without a switch for civil servants, but not for health care professionals in $2004 .{ }^{21}$ However, possible second order general equilibrium effects of the policy change are not likely to be quantitatively more important than the first order effect of decreasing transaction costs for individual workers.

\footnotetext{
21 The percentage of civil servants who do not switch jobs and receive a promotion increases from $15 \%$ to $20 \%$ according to the multinomial logit estimates. This increase is solely driven by the individuals for whom $w>r$. Results available from the author on request.
} 


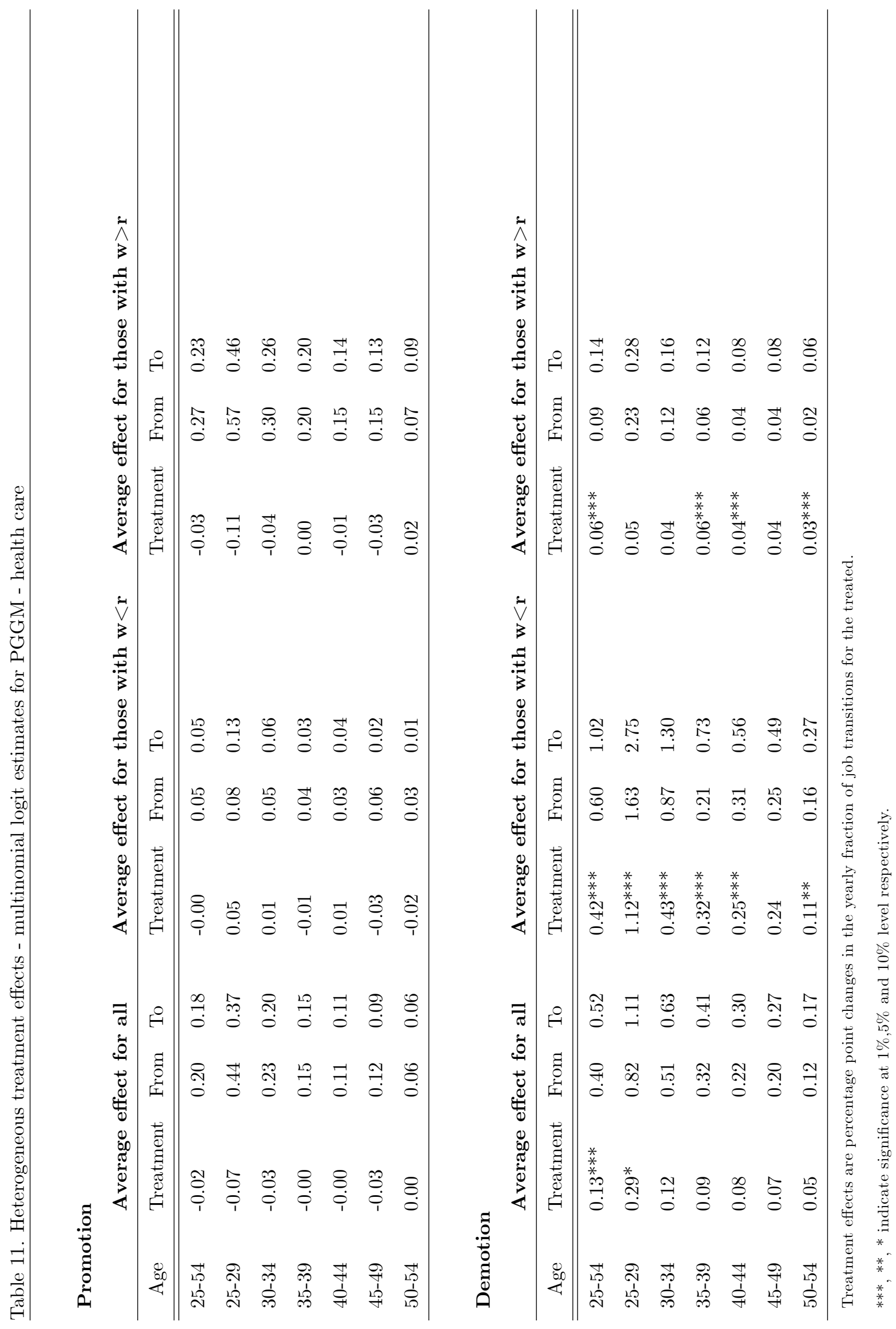




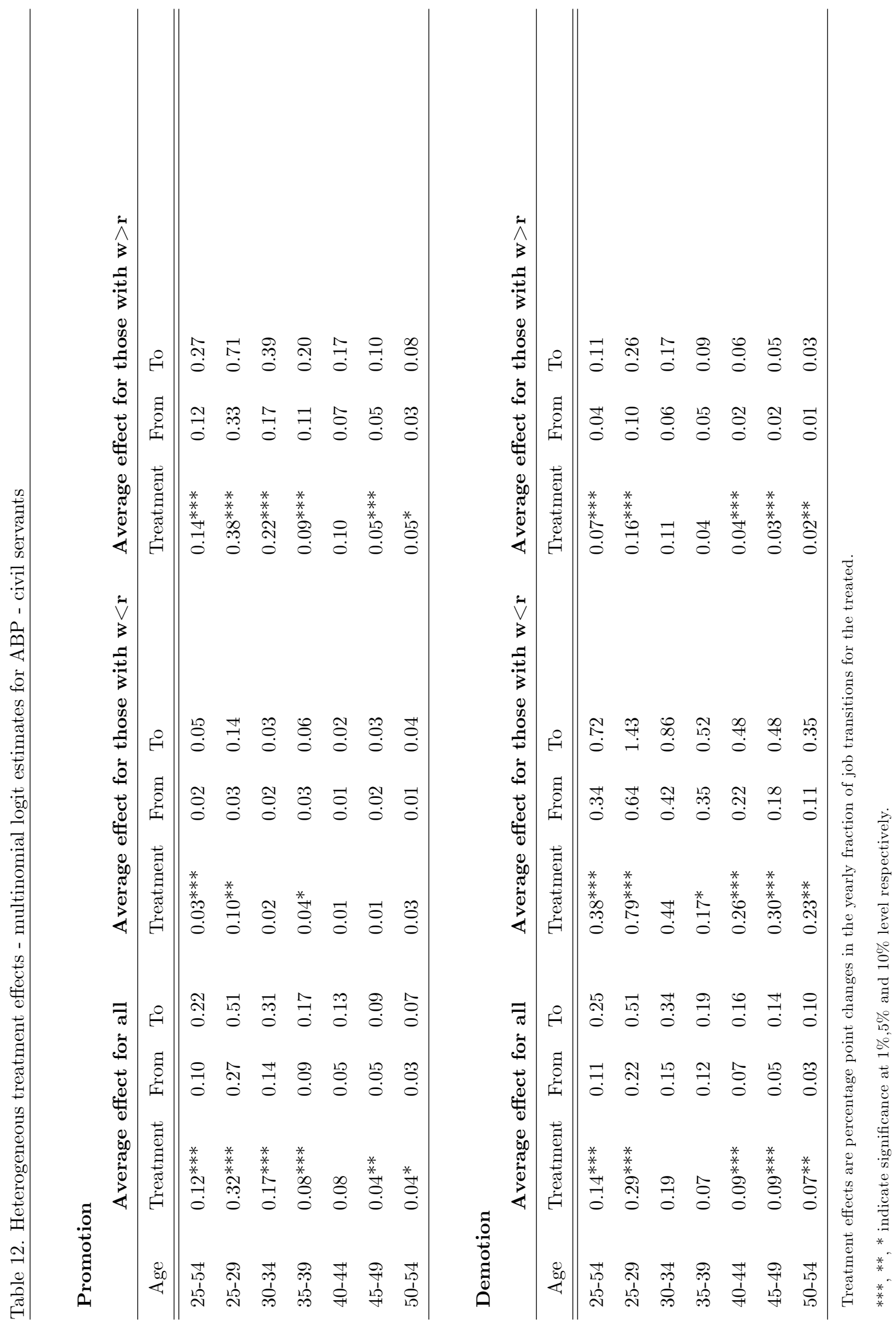




\section{Conclusions}

This paper studies the effect of financial incentives embedded in the pension system on job mobility. A career-making individual with a high expected future wage increase who is employed on a job offering a (backloaded) DB-final salary pension scheme will suffer a loss in pension wealth when switching jobs, even when the new job offers an equally favourable DB-final salary pension. This loss occurs especially when pension rights cannot be transferred to the new job. On the other hand, an individual with a low expected wage increase will gain pension wealth when transferring to a job offering a DB-average salary pension. When the current job offers a DB-average salary pension scheme, pension wealth will not be affected from a transfer to a job which offers an equally favourable DB-average salary scheme. On average, one would expect that (backloaded) DB-final salary pensions can lock an individual in his job, thereby decreasing job mobility. Indeed, this study shows that Dutch employees who are covered by a DB-average salary plan are much more likely to switch jobs than individuals covered by a DB-final salary plan. Other studies already showed that employees with jobs that do have pension coverage are less likely to switch jobs than employees with jobs without pension coverage. However, these studies were not able to identify a causal effect from having a backloaded pension plan on a lower propensity to switch jobs. An alternative explanation is that less switch-prone individuals self-select into jobs with a pension plan, or that jobs offering a pension plan are simply more attractive than other jobs.

This paper makes use of a natural experiment to examine effects of potential capital losses and general attractiveness of pension schemes on employees' propensity to change jobs. On January 1st 2004, the two largest pension funds in the Netherlands, for civil servants and for the health care sector, changed their pension scheme from DB-final salary to DB-average salary. The two pension schemes were effectively offered to the same indiviuals, such that our results cannot be driven by any self-selection of individuals into jobs with an attractive pension scheme. The empirical results show that the onset of the DB-average salary pension scheme in 2004 coincided with an increase in the propensity to change jobs. Specifically, the percentage of yearly job switches increases with 0.08 percentage points for employees working in the health care sector (i.e. from $1.23 \%$ to $1.30 \%$ ). The percentage of yearly job switches increases with 0.61 percentage points for employees working as civil servants (i.e. from $0.64 \%$ to $1.25 \%$ ). However, the estimates for both civil servants and health care professionals are not in line with the hypotheses that job mobility should especially increase for career-making employees who made a promotion at the time of the switch, and for those with a high subsequent wage growth in the new job. Observed behaviour is therefore not in agreement with the theoretical incentives in the pension system. Our results can be interpreted in two ways. First, it can be that

individual workers do react on a major change in their pension system, but do not pay much attention to the details of their pension scheme. Second, it can be that individual workers are interested in their pension scheme, but have a hard time understanding the impact of rules and regulations embedded in the pension system on their (future) income. 


\section{References}

Allen, S.G. and R.L. Clark (1987), Pensions and firm performance, NBER Working Paper No. 2266

Allen, S.G., Clark, R.L. and A.A. McDermed (1993), Pensions, bonding, and lifetime jobs, The Journal of Human Resources (28:3) 463-481

Andrietti, V. (2004), Pension choices and job mobility in the UK, Working Paper 04-37 Economics Series 13, Universidad Carlos III de Madrid

Andrietti, V., and V.A. Hildebrand (2016). Evaluating pension portability reforms: the tax reform act of 1986 as a natural experiment, Economic Inquiry (54:3) 1402-1424

Börsch-Supan, A. and R. Schnabel (1998), Social Security and Declining Labor-Force Participation in Germany, The American Economic Review Papers and Proceedings (88:2) 173-178

Bovenberg, A.L. and A.C. Meijdam (1999), The Dutch pension system, mimeo, Tilburg University

Burtless, G. and R.A. Moffitt (1984), The effect of social security benefits on the labor supply of the aged.

In H.J. Aaron \& G. Burtless (Eds.), Retirement and Economic Behavior, Washington DC: The Brookings Institute

Di Tella R, and R. MacCulloch (2005). The consequences of labor market flexibility. European Economic Review (49) 1225-1259.

Euwals, R., van Vuuren, D. and R. Wolthoff (2010), Early retirement behaviour in the Netherlands: evidence from a policy reform, De Economist (158) 209-236

Gruber J., and B.C. Madrian (1994), Health Insurance and job mobility: the effects of public policy on job-lock, Industrial and Labor Relations Review 48(1), 86-102

Gustman, A. and T. Steinmeier (1993), Pension portability and labor mobility: evidence from the Survey of Income and Program Participation, Journal of Public Economics (50) 299-323

Henley, A., Disney, R. and A. Carruth (1994), Job tenure and asset holdings, The Economic Journal (104:432) 338-349

Ippolito, R.A. (1991), Encouraging long-term tenure: wage tilt or pensions?, Industrial and Labor Relations Review (44:3) 520-535

Ippolito, R.A. (2002), Stayers as "workers" and "savers": toward reconciling the pension-quit literature, The Journal of Human Resources (37:2) 275-308

Martin, J.P. and E. Whitehouse (2008). Reforming Retirement-Income Systems: Lessons from the Recent Experiences of OECD Countries. IZA Discussion Paper No. 3521

Mealli, F. and S. Pudney (1996), Occupational pensions and job mobility in Britain: estimation of a random effects competing risks model, Journal of Applied Econometrics (11) 293-320

Mitchell, O.S. (1982), Fringe benefits and labor mobility, Journal of Human Resources (17) 286-298

OECD (2005), Solving the pensions puzzle. March 2005 policy brief.

OECD (2015), Pensions at a Glance 2015: OECD and G20 indicators, OECD Publishing.

OECD (2016). OECD Pensions Outlook 2016. OECD Publishing. 
Ponds, E. H. M. and van Riel, B. (2009) Sharing risk : The Netherlands' new approach to pensions, Journal of Pension Economics and Finance (8) 91-105

Royalty, A.B. (1998), Job-to-job and job-to-nonemployment turnover by gender and education level, Journal of Labor Economics (16:2) 392-433

Statistics Netherlands (2012). Pensioenfondsen; deelnemers en premies. Obtained February 5th 2012, from http://statline.cbs.nl/StatWeb/publication/?VW=T\&DM=SLNL\&PA=37179pfd\&D1=0,2-4,9\&D2=a\&D3=(l6) $-1 \& \mathrm{HD}=091110-1009 \& \mathrm{HDR}=\mathrm{G} 2, \mathrm{G} 1, \mathrm{~T}$.

Thomas A., and L. Spataro (2016). The effects of pension funds on markets performance: a review. Journal of Economics Surveys (30:1) 1-33

van den Berg G. (1992), A structural dynamic analysis of job turnover and the costs associated with moving to another job, Economic Journal 414, 1116-1133. 